\title{
KONSTRUKSI REALITAS BERITA ANIES BASWEDAN DAN PSBB DI HARIAN TEMPO.CO
}

\author{
Erna Megawati ${ }^{1}$, Sangaji Niken Hapsari², ${ }^{2}$ riarti Megawanti ${ }^{3}$ \\ Fakultas Bahasa dan Seni, Universitas Indraprasta PGRI \\ 145megawatie@gmail.com, ${ }^{2}$ nikeko0804@gmail.com, ${ }^{3}$ priartimegawanti@gmail.com
}

\begin{abstract}
Abstrak
Kebijakan memberlakukan kembali PSBB yang dilakukan oleh Gubernur DKI Jakarta sejak 14 September 2020 telah menuai pro dan kontra di masyarakat. Surat kabar daring tidak ketinggalan menghadirkan realitas pro dan kontra ini. Penelitian ini bertujuan untuk menganalisis konstruksi realitas berita Anies Baswedan dan PSBB di harian daring Tempo.co. Metode pengumpulan data dalam penelitian yaitu metode simak dan metode pustaka. Data dianalisis dengan mengunakan AWK Norman Fairclough melalui tiga tahap, yakni tahap deskripsi, interpretasi, dan eksplanasi dan Teori Konsep Appraisal. Hasil penelitian menunjukkan bahwa di harian Tempo.com konstruksi Anies Baswedan ditampilkan dengan kosakata berupa verba, adverbial, metafora dan modalitas. Hasil analisis pada gramatika menunjukkan penggunaan konstruksi aktif, pasif serta negasi. Sistem Appraisal yang dihadirkan pada wacana ini dilakukan dari tataran sikap dengan menggunakan afeksi kata sifat, kata benda, dan kata kerja serta penghakiman negatif. Pada tataran amplifikasi, terdapat amplifikasi kekuatan intensifier negatif dengan leksis sikap dan metafora serta fokus yang menguat dan menurun. Dari tinjauan sumber sikap, pewarta menggunakan heteregloss oleh pewarta dan sumber lain yang dikutip pewarta untuk mengevaluasi objek evaluasi, Anies Baswedan dan Kebijakan PSBB.
\end{abstract}

Kata Kunci: Anies Baswedan, PSBB, Media Daring.

\begin{abstract}
The policy of reintroducing the PSBB, which was carried out by the Governor of DKI Jakarta since September 14, 2020, has drawn pros and cons in the community. Online newspapers were not left behind in presenting the realities of these pros and cons. This study aims to analyze the construction of the reality of Anies Baswedan and PSBB news in the online daily Tempo.co. Data collection methods in this research were observation method and library method. Data were analyzed using AWK Norman Fairclough through three stages, namely the description, interpretation and explanation stages and the Appraisal Concept Theory. The results showed that in the daily Tempo.com Anies Baswedan's construction was displayed with vocabulary in the form of verbs, adverbials, metaphors and modalities. The results of the analysis on grammar showed the use of active, passive and negation constructs. The Appraisal system presented in this discourse was carried out from an attitude level using adjective, noun and verb affection as well as negative judgment. At the level of amplification, there was amplification of the power of negative intensifiers with a lexic of attitudes and metaphors as well as a strong and decreased focus. From the review of attitude sources, the journalits used heteregloss by the journalits and other sources quoted by the journalits to evaluate the object of evaluation, Anies Baswedan and PSBB Policy.
\end{abstract}

Keywords: Anies Baswedan, PSBB, Online Media 


\section{PENDAHULUAN}

Pandemi, kata yang dulu asing telah bertransformasi menjadi keseharian yang memaksa semua manusia berubah atau terlindas. Semua wajah berusaha menyesuaikan dengan tuntutan pandemi. Bukan hanya kelompok minoritas yang menjadi sasaran perubahan, tetapi juga para pemangku kebijakan. Semua dipaksa berpikir cepat dan tepat walau tidak jarang yang meleset. Berbagai kebijkan dikeluarkan dalam usaha penyesuaian tersebut, di antaranya PSBB.

PSBB atau Pembatasan Sosial Berskala Besar mulai diberlakukan oleh pemerintah provinsi DKI Jakarta dari bulan Maret 2020 hingga awal Juni 2020 di bawah komando Gubernur Anies Baswedan. Anies Rasyid Baswedan terpilih menjadi gubernur DKI Jakarta pada tahun 2017 mengalahkan incumbent Basuki Tjahaja Purnama atau yang akrab dipanggil Ahok. Sejak awal kepemimpinannya, Anies dianggap melakukan blunder dengan menggunakan kata pribumi (Simanjuntak, 2018). Anies pula kepala daerah pertama yang menerapkan PSBB di wilayahnya, DKI Jakarta (Syarifuddinn, 2020). Setelah usai dengan PSBB jilid 1 yang dilanjutkan dengan PSBB transisi, kini Anies Baswedan menarik rem darurat untuk memberlakukan PSBB pengetatan sejak tanggal 14 September 2020. PSBB ini dilaksanakan dengan dasar hukum Pergub Nomor 88 tahun 2020 yang berkaitan dengan perubahan Pergub Nomor 33 tahun 2020 mengenai PSBB. Pergub ini diterbitkan pada tanggal 13 September 2020. Berbagai media memuat pemberitaan mengenai Anies dan kebijakan PSBB-nya dengan menggunakan teropongnya masing-masing,

Kebijakan ini diharapkan efektif menekan laju perkembangan pandemi sebagai opsi pengganti lock down. Ada pihak yang menganggap PSBB efektif, seperti yang diungkap oleh Maulana (2020) dalam penelitiannya Efektivitas Pembatasan Sosial Berskala Besar (PSBB) Sebagai Salah Satu Upaya Menekan Penyebaran Covid-19 Di DKI Jakarta. Sebaliknya, Sulasih (2020) dalam penelitiannya Ketidakefektifan Penerapan Pembatasan Sosial Berskala Besar (PSBB) di Daerah Khusus Ibukota Jakarta menunjukkan bahwa PSBB tidak efektif pelaksanaannya yang disebabkan kurangnya kesadaran hukum dari masyarakat, dampak terhadap ekonomi masyarakat menengah ke bawah, serta terjadinya tindak kriminalitas, dan ketidaktertiban para pengguna jalan.

Dua penelitian dengan hasil yang kontra ini menegaskan bahwa suatu masalah dapat saja disorot dari dua atau lebih cara pandang sehingga menghasilkan sesuatu yang berbeda. Dalam sorotan analisis wacana kritis, bahasa, ideologi, dan kekuasaan adalah tiga entitas yang saling berkaitan. Bahasa tidaklah lahir dan dimaknakan di ruang hampa karena di dalam bahasa terdapat seperangkat sistem nilai serta keyakinan yang dikenal sebagai ideologi. Ketika Ideologi menjadi keyakinan kelompok sosial dominan, ideologi tersebut dimediasi melalui institusi politik dan sosial yang kuat, seperti pemerintah, hukum, serta profesi medis. Hal inilah yang menjadi kajian utama dari linguistik kritis adalah bahasa mereproduksi ideologi yang pada akhirnya digunakan untuk memeroleh kekuasaan (Simpson, 1993: 5). Sejalan dengan Simpson, Fairclough (1996) menjelaskan bahwa bahasa terkait dengan kekuasaan, baik dalam wacana dan kekuasaan di luar wacana. Kekuasaan dalam wacana sebagai tempat di mana hubungan kekuasaan benarbenar dinyatakan maupun kekuasaan tersembunyi di dalam media massa.

Peran media pada hakikatnya merupakan alat peyampai informasi pada khalayak. Sebuah wacana berita sebagai bentuk bahasa tidak hanya dipandang secara tekstual semata. Dalam pandangan Altussher (1970) media berperan sebagai pembentuk opini publik yang akan memberi dampak pada perubahan sosial serta media sebagai aparat 
ideologis untuk memproduksi kebenaran dan kenyataan (Hall, 1991). Media memiliki caranya sendiri dalam merepresentasikan realitas, termasuk realitas para pelaku kebijakan dalam hal ini Anies Baswedan selaku Gubernur DKI Jakarta.

Dalam pandangan Fairclough (1996) wacana adalah bentuk praktik sosial di mana bahasa dianggap sebagai bagian dari masyarakat yang lahir sebagai proses sosial. Wacana merupakan keseluruhan proses interaksi sosial di mana teks berada yang meliputi produksi dan interpretasi proses tersebut melibatkan faktor sosial berupa faktor nonlinguistik yang memengaruhi teks. Kondisi sosial tersebut meliputi kondisi sosial produksi, serta nterpretasi. Kondisi ini terangkai dengan tiga tingkatan organisasi sosial yakni lingkungan sosial di mana wacana terjadi; institusi sosial sebagai lingkungan sosial wacana yang lebih luas dari wacana; dan lingkungan sosial keseluruhan. Jadi, bahasa sebagai suatu praktik sosial tidak hanya bisa dipandang dari sudut tekstual, tetapi harus dianalisis dari sudut hubungan antarteks, proses, dan kondisi sosialnya, kondisi sosial di mana wacana berlangsung dan juga kondisi sosial yang lebih luas dari wacana tersebut.

Untuk menganalisis teks dengan AWK Fairclough, diperlukan interpretasi mengenai konteks berupa konteks situasi. Norman Fairclough membagi wacana ke dalam tiga dimensi, yakni tekstual, analisis, wacana, dan praktik sosial. Data kemudian dianalisis ke dalam tiga tahapan, yaitu deskripsi, interpretasi, dan eksplanasi (Fairclough, 1995). Tahap deskripsi Analisis ini digunakan untuk menganalisis fitur kebahasaan berupa analisis kohesi gramatikal (referensi, ellipsis, subtitusi, serta konjungsi) dan leksikal serta koherensi, kemudian analisis interpretasi dalam rangka menelusuri hubungan antarteks serta interaksi di dalam teks. Analisis ini memandang teks sebagai proses produksi serta sumber di dalam proses interpretasi. Pada tahap ini, teks ditinjau dengan melibatkan faktor sosial sebagai interpretasi konteks seperti siapa yang terlibat, apa hubungan yang terjalin dan bagaimana peran bahasa dalam teks tersebut. Interpretasi merupakan generalisasi dari apa yang terdapat di teks serta apa yang menjadi benak sang interpreter (Fairclough, 1996). Analisis eksplanasi berupa praktik sosial berdasar konteks sosial di luar teks yang dianalisis dari tingkat situasional, institusional, serta sosial. Tahapan ini terkait dengan hubungan yang terbentuk antara konteks interaksi dan sosial. Pada tahap ini sering muncul pertanyaan mengenai hal apa yang membantu pembentukan wacana serta bagaimana muatan ideologis digambarkan dalam wacana.

Dalam kaitan nilai ekspresif pada AWK Fairclough, terdapat dua macam evaluasi yang disajikan yakni evaluasi positif dan negatif. Untuk melakukan evaluasi digunakan konsep Apraisal yang dikemukakan White dan kemudian dikembangkan oleh Martin dan Rose (Nurdiyani, 2020). Evaluasi merupakan penilaian pada bahasa yang digunakan seseorang dalam menyampaikan perasaannya atau pendapatnya yang sejalan dengan orang lain serta untuk menunjukkan kekuatan dan kelemahan proposisinya. Evaluasi ini membantu dalam menentukan apakah media terkait cenderung memberikan evaluasi positif atau negatif. Martin dan Rose (2003: 22-65) menyatakan bahwa dalam sistem evaluasi terdapat tiga aspek yakni sikap, amplifikasi, dan sumber sikap.

Kategori sikap berkaitan dengan perasaan pewarta terhadap sesuau atau seseorang yang tercermin mellaui lisan atau tulisan. Sikap terbagi menjadi afeksi, penilaian, dan apresiasi, afeksi dapat ditunjukkan dengan kata sifat seperti benci, marah, senang atau dengan menggunakan kata keterangan seperti dengan bahagia, dengan kebencian, serta dengan menggunakan nominalisasi seperti kemarahan, kesedihan, dan kebencian. Aspek penilaian dapat berupa penilaian positif atau negatif terhadap perilaku manusia. Penilaian ini bisa berupa penghargaan dan sanksi. Penilaian penghargaan berhubungan dengan kenormalan, kapasitas, dan kegigihan. Sementara penilaian sanksi berkaitan dengan 
kejujuran dan kepantasan. Sedangkan aspek apresiasi berkaitan dengan penilaian secara estetis (Martin \& White, 2005).

Aspek amplifikasi merupakan penguatan sikap dalam taraf makna. Amplifikasi dibedakan menjadi kekuatan dan fokus. Amplifikasi kekuatan yang dihubungkan dengan volume amplifier dikategorikan menjadi meninggi dan menurun. Amplifikasi ini terdiri dari intensifier, leksis sikap, metafora, serta umpatan. Untuk amplifikasi fokus dibagi menjadi menguat dan menurun dengan menggunakan diksi dengan gradasi terukur seperti harus, boleh, atau bisa (Wiratno, 2018).

Evaluasi dari sumber sikap adalah menyoroti sumber sikap yang direalisasikan atau dari siapak evaluasi bersumber. Sumber sikap bisa berasal dari banyak sumber yang bukan hanya pewarta saja atau berasal dari penulis. Penggunaan banyak sumber (heterogloss engagement) memungkinkan berita lebih terkesan objektif dan akurat.

Penelitian relevan yang berkaitan dengan Anies Baswedan dalam kerangka konstruksi media telah banyak dilakukan di antaranya oleh Simanjuntak (2018) dengan judul Analisis Semiotik Pidato Pelantikan GubernurDKI Jakarta Anies Baswedan yang bertujuan mengritisi serta menginterpretasikan pidato Gubernur DKI Jakarta secara deskriptif. Hasil penelitian menunjukkan bahwa Anies menggunakan emergency word dalam rangka menunjukkan rasa ketidakadilan. Penelitian serupa juga dilakukan oleh Andriyanto (2018) yang berjudul Konstruksi Berita Pasca Pelantikan Gubernur Baru Dki Jakarta Anies Baswedan-Sandiaga Uno Periode 2017-2022 (Analisis Framing Robert N. Entman Pada Media Online Kompas. Com, Detik. Com, Dan Republika. Co. Id) yang bertujuan mengupas kostruksi realitas berita pascapelantikan Gubernur DKI Jakarta, Anies Baswedan, yang disajikan di media daring Kompas.com, Detik.com, dan Republika.co.id. penelitian menunjukkan bahwa media Kompas.com bersikap cenderung mengritisi kebijakan pasangan Anies-Sandiaga, sedangkan media Detik.com ditemukan lebih netral dalam memberitakan, sedangkan Republika.co.id ditemui memiliki kecenderungan membela kebijakan yang diambil oleh Anies-Sandiaga.

Penelitian relevan di atas mendorong peneliti untuk melakukan analisis perbandingan konstruksi realitas Anies Baswedan dan PSBB dalam media daring Tempo.co karena belum ada penelitian yang mengangkat konstruksi realitas berita Anies Baswedan dan kebijakan PSBB dari dua sorotan yang AWK Fairclough dan Teori Apraisal Martin \& White. Penelitian ini menjadi penting dilakukan guna mengedukasi agar berpikir kritis dalam menanggapi berbagai berita yang disajikan ke khalayak. Adapun alasan pemilihan sumber data, Tempo.com, karena menurut www.centerklik.com, portal Tempo.co di bawah direktur utama Toriq Hadad masuk dalam 10 portal daring terbaik dan juga berhasil menjadi juara dunia dalam kompetisi hackathon media, yang diselenggarakan oleh asosiasi Global Editors Network di Wina, Austria pada 17 Juni 2016. Alasan-alasan tersebut yang mendorong peneliti untuk menjadikan media daring Tempo.co sebagai sumber data penelitian ini.

Berdasarkan latar belakang di atas, peneliti hendak melakukan penelitian untuk menjawab pertanyaan: Bagaimana konstruksi realitas berita Anies Baswedan dan PSBB di media daring Tempo.co dari perspektif AWK Fairclough dan Konsep Appraisal?

\section{METODE PENELITIAN}

Desain penelitian ini dilakukan dengan menggunakan analisis wacana kritis (AWK) model Norman Fairclough. Data dianalisis ke dalam tiga tahapan, yaitu deskripsi, interpretasi, dan eksplanasi serta Konsep Appraisal. Kerangka tersebut akan digunakan 
untuk menganalisis teks berita mengenai Anies Baswedan dan PSBB DKI Jakarta di media daring Tempo.co.

Sumber data diambil dari portal media daring Tempo.co dan Media Indonesia.com dengan tema berita berupa Anies Baswedan dan kebijakan PSBB DKI Jakarta yang dipublikasi pada bulan September 2020. Unit analisis penelitian ini berupa kutipan di dalam media daring Tempo.co dan Media Indonesia.com yang mengandung tema berita berupa Anies Baswedan dan kebijakan PSBB DKI Jakarta. Data dikumpulkan dengan teknik simak dan catat (Mahsun, 2012).

Prosedur penelitian dilakukan melalui tahapan pengumpulan data, pengelompokan data sesuai sumber pengambilannya, data dianalisis secara tekstual, dan penarikan simpulan. Keabsahan penelitian ini dilakukan dengan menggunakan teknik triangulasi sumber.

Berikut ini adalah diagram penelitian:

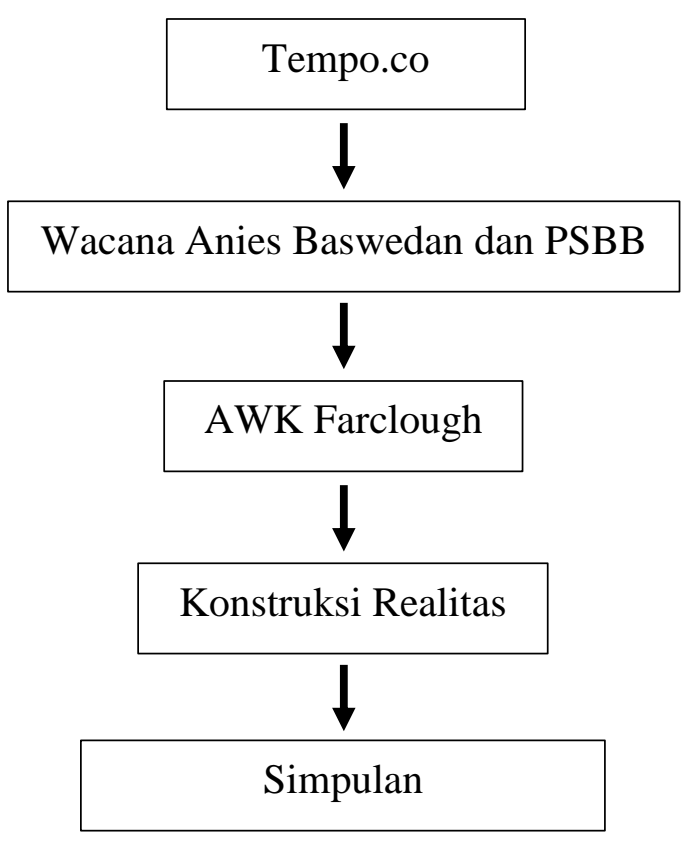

Diagram 1 Alur Penelitian

\section{HASIL DAN PEMBAHASAN}

Pada bagian ini akan dipaparkan hasil analisis wacana kritis terhadap konstruksi realitas berita dengan topik Anis Baswedan dan kebijakan PSBB DKI Jakarta pada media daring Tempo.co. Analisis ini dilakukan dengan tiga dimensi teksual dalam tiga tahap yaitu deskripsi, interpretasi, dan eksplanasi. Dimensi tekstual dalam sudut pandang AWK Fairclough mencakup uraian kosakata, gramatika serta sruktur tesktual. Data juga dianalisis dengan teori Apraisal untuk mengevaluasi.

Terdapat 22 tajuk berita di Tempo.co yang bertemakan Anies Baswedan pada periode bulan September 2020. Hal ini menunjukkan bahwa berita yang berkaitan dengan Anies Baswedan termasuk ke dalam topik pilihan dan terhangat. Dari 22 berita dengan topik Anies Baswedan, peneliti memilih tajuk yang mengangkat kebijakan PSBB DKI Jakarta dengan judul Covid-19 Tak Terkendali di Masa Transisi, Anies Baswedan Injak Rem Darurat PSBB. Berikut ini keterangan tajuk tersebut serta waktu publikasinya: 
Tabel 1 Data Tajuk di Tempo.com

\begin{tabular}{clll}
\hline No & \multicolumn{1}{c}{ Tajuk Berita } & Tanggal Publikasi & \multicolumn{1}{c}{ Reporter } \\
\hline 1 & Covid-19 Tak Terkendali di Masa & Jumat, 11 & Imam Hamdi \\
& Transisi, Anies Baswedan Injak & September 2020 & \\
Rem Darurat PSBB & 20:57 WIB &
\end{tabular}

Sumber: Tempo.co

1. Gubernur DKI Jakarta Anies Baswedan akhirnya memilih menginjak rem darurat masa transisi dan kembali ke pembatasan sosial berskala besar ( $\underline{\text { PSBB }})$. Masa transisi selama 3 bulan terbukti gagal membuat masyarakat mau beradaptasi dengan kebiasaan baru atau new normal. "Hal itu (rem darurat) dilakukan untuk menekan angka penularan Covid-19 yang semakin naik pada PSBB Masa Transisi Fase 1," ujar Anies melalui keterangan resminya yang disampaikan pada Rabu malam, 9 September 2020.

Kutipan ini menggunakan adverbial akhirnya yang pada KBBI bermakna kesudahannya yang menunjukkan akhir dari suatu proses atau penantian. Hal ini memberikan persepsi bahwa pengambilan kebijakan PSBB yang dilakukan oleh Anies Baswedan merupakan tindakan yang sudah diprediksi sebagai alternatif akhir. Penggunaan kata gagal yang bermakna tidak berhasil mencapai tujuan yang menggambarkan bahwa kebijakan terdahulu yang diambil oleh Anies tidaklah berhasil. Kata gagal bersinonim dengan kata yang lebih netral seperti batal atau tidak berhasil. Secara gramatikal, pewarta menggunakan pasifasi pada kutipan Hal itu (rem darurat) dilakukan untuk menekan angka penularan Covid-19. Fairclough (1996) menjelaskan bahwa proses pasifasi bertujuan untuk menghilangkan pelaku yang bertujuan melindungi agen dan juga menghindari pemborosan kata. Pada penggalan tersebut, Anies Baswedan menggunakan modalitas untuk yang menunjukkan tujuan dari tindakan yang diambil. Dengan demikian, pilihan wartawan memasukkan kutipan langsung menghadirkan kembali agen atau subjek tindakan agar diketahui oleh mitra tutur.

Pendayagunaan kosa kata ideologis metafora menginjak rem darurat merupakan strategi untuk melancarkan maksud kepada mitra tutur yang memberikan persepsi bahwa ini adalah tindakan yang sangat perlu dilakukan yang disebabkan kondisi darurat. Kosakata ideologis rem darurat yang merupakan metafora dari kebijakan yang diambil oleh pemerintah pada kondisi darurat. Dalam kaitan dengan aspek gramatikal, Gubernur DKI Jakarta Anies Baswedan akhirnya memilih menginjak rem darurat masa transisi bentuk yang digunakan merupakan ketransitifan dengan konstruksi aktif $(\mathrm{S}+\mathrm{Pr}+\mathrm{O})$ dengan bentuk pola tindakan. Konstruksi ini menunjukkan bahwa wartawan hendak menampilkan sosok pelaku tindakan agar diketahui oleh masyarakat sebagai mitra tutur. Dengan demikian, pewarta hendak mengarahkan apapun akibat yang ditimbulkan dari kebijakan ini akan direlasikan dengan pengambil keputusan tersebut.

Ditinjau dari teori Appraisal, kutipan di atas pemilihan kata gagal disini sikap penghakiman yang ditunjukkan pewarta adalah negatif, terlebih kata tersebut dipadankan dengan kata terbukti, sedangkan amplifikasi yang digunakan adalah 
kekuatan negatif dengan menggunakan metafora yaitu frasa rem darurat. Penggunaan metafora ini ditujukan untuk memudahkan pemahaman pembaca mengenai kondisi saat ini. Dari aspek sumber sikap, pewarta menggunakan heterogloss yaitu pewarta dan Anies Baswedan. Pewarta sebagai subjek evaluasi hendak memberikan evaluasi negatif terhadap kebijakan PSBB transisi atau new normal yang diterapkan oleh Anies Baswedan sebagai objek evaluasi pada 3 bulan terakhir. Sulasih (2020) yang mengungkapkan dengan bahasa yang lebih netral bahwa faktor ketidakefektifan tersebut berasal kurangnya kesadaran masyarakat. Hal ini berlawanan dengan harapan masyarakat pada awal PSBB transisi di mana masyarakat berharap PSBB transisi dapat memulihkan kehidupan masyarakat dan dunia usaha (Judge dkk., 2020).

2. Pada masa PSBB Transisi Fase, angka positivity rate Covid-19 di Ibu Kota melonjak hingga menyentuh 13 persen. Padahal saat PSBB, rasio kasus positif DKI sempat di bawah 5 persen. Anies Baswedan pernah bilang tak segan menginjak rem darurat kembali ke PSBB jika angka positivity rate di atas 10 persen, atau kategori bahaya. Dokter di RS rujukan Covid-19 sudah kewalahan karena pasien yang terus berdatangan sementara ruang isolasi dan ICU hampir penuh terisi. Kabar buruk lain datang dari TPU Pondok Ranggon yang diperkirakan bakal penuh terisi makam jenazah Covid-19 dalam dua bulan ke depan.

Dari aspek kosakata, berita ini menggunakan diksi melonjak untuk menunjukkan angka positivity rate. Kata melonjak bersinonim dengan kata meningkat, meninggi, dan juga berkembang. Namun, kata melonjak memiliki nilai mengalami peningkatan secara mendadak. Melalui pemilihan kata melonjak, wartawan seolah mau mengesankan jika ini adalah sebuah peningkatan yang tidak diantisipasikan sekaligus mau mengesankan bahwa kebijakan yang diterapkan saat ini mengalami kegagalan. Selain itu, berita ini menggunakan penegasian tak segan. Penegasian digunakan untuk menyangkal apa yang dinyatakan oleh lawan bicara.

Sistem appraisal berupa sikap yang digunakan afeksi negatif dengan menggunakan kata kerja kewalahan. Penggunaan kata tersebut dapat memunculkan reaksi emosional bagi pembaca berupa rasa keputusasaan dari para tenaga kesehatan menghadapi situasi tersebut, sedangkan dari aspek amplifikasi, pewarta menggunakan amplifikasi kekuatan meninggi dengan adanya kata dan frasa melonjak, hingga, hampir, bakal penuh, dan kabar buruk lain. Melalui penggunaan kata dan frasa tersebut pewarta seperti menguatkan betapa parahnya kondisi DKI Jakarta akibat pandemi. Untuk aspek sumber sikap, kutipan di sini menggunakan heterogloss yaitu pewarta dan Anies. Dalam tulisannya seolah pewarta ingin menunjukkan ke pembaca bahwa tulisannya adalah suatu yang objektif dan akurat.

3. Anies berujar indikator utama keputusan menghentikan masa transisi adalah tingkat kematian (Case Fatality Rate) dan tingkat keterisian rumah sakit (Bed Occupancy Ratio) baik untuk tempat tidur isolasi, maupun ICU yang semakin tinggi. Tingkat kematian dan keterisian rumah sakit rujukan Covid-19 telah menunjukkan kondisi darurat. "Maka, dengan melihat kedaruratan ini, tidak ada pilihan lain bagi Jakarta kecuali untuk menarik rem darurat segera," ucapnya.

Dari aspek kosakata, kutipan tersebut menggunakan diksi menghentikan yang secara leksikal bermakna meminta sesuatu berhenti atau menyebabkan sesuatu berhenti (https://id.wiktionary.org/wiki/menghentikan). Kata ini menunjukkan bahwa ada faktor yang menyebabkan agen mengambil keputusan untuk menghentikan, dalam hal ini tingkat kematian dan tingkat keterisian rumah sakit. 
Kutipan ini dari aspek gramatikal berupa bentuk ketransitifan menunjukkan adanya agen, yaitu Anies. Anies dalam tradisi Halliday berlaku sebagai partisipan yang menempati posisi sebagai subjek logis atau pelaku tindakan (Halliday \& Matthiessen, 2013).

Ditinjau dari sistem appraisal sikap penghakiman negatif, pewarta kembali menggunakan kata darurat yang bermakna keadaan sukar atau sulit yang tidak disangka yang harus segera ditangani (https://kbbi.web.id/darurat). Pewarta juga menggunakan afeksi negatif dengan kata kematian. Pewarta seolah ingin memicu reaksi dari pembaca mengenai keadaan darurat yang akan diikuti dengan kematian. Dari sudut amplifikasi, pewarta menggunakan amplifikasi kekuatan meninggi melalui intensifier negatif dengan kata semakin tinggi dan tidak ada pilihan lain. Pewarta hendak menguatkan bahwa kondisi saat ini dibanding dengan sebelumnya yang mengalami peningkatan sehingga PSBB merupakan pilihan terakhir yang bisa diambil. Untuk appraisal sumber sikap, pewarta masih mengunakan heteregloss berupa penggunaan sumber dirinya sendiri dan nara sumber yang pendapatnya dikutip sebagai penguat tulisannya.

4. Dengan penerapan kembali PSBB Jilid 2 mulai 14 September 2020, Anies kembali membatasi kegiatan ekonomi dan sosial seperti saat PSBB Jilid 1 pada 10 April hingga 4 Juni lalu. Selama PSBB diterapkan, Pemerintah DKI melarang kegiatan perkantoran beroperasi kecuali 11 bidang usaha esensial yang boleh tetap berjalan dengan operasi minimal. Adapun seluruh izin operasi tambahan bagi bidang usaha non esensial yang didapatkan ketika masa awal PSBB dahulu, baik oleh Pemprov DKI maupun oleh Kementerian Perindustrian, tidak lagi berlaku dan harus mendapatkan evaluasi ulang bila merasa perlu mendapat pengecualian. "Selain itu, seluruh tempat hiburan harus tutup," ujarnya

Dari aspek kosakata, kutipan tersebut menggunakan diksi kembali yang berarti lagi atau berulang. Hal ini menunjukkan bahwa kegiatan yang dilakukan merupakan kegiatan yang pernah dilakukan, dalam hal ini kegiatan membatasi. Kata membatasi yang dimaksud adalah kebijakan PSBB. Dari aspek gramatikal, konstruksi yang digunakan adalah ketransitifan yang menunjukkan agen/aktor yang melakukan kerja, dalam hal ini Anies. Sistem evaluasi sumber yang digunakan oleh pewarta adalah nara sumber. Wartawan bukannya menggunakan kata Pemerintah Daerah malah menggunakan diksis Anies sebagai aktor tindakan tersebut. Sebaliknya pada kalimat selanjutnya, pewarta memunculkan Pemerintah Daerah sebagai aktor tindakan. Tindakan yang dimaksud adalah melarang kegiatan kantor. Diksis melarang memiliki makna memerintahkan supaya tidak melaksanakan sesuatu (https://kbbi.web.id/larang). Dari tinjauan gramatikal, pewarta menggunakan ketransitifan dengan frasa kegiatan perkantoran sebagai objek dari predikasi. Bentuk ketransitifan ini dengan susunan aktor, proses perbuatan, sasaran. Dari kalimat ini, terlihat bahwa aktor adalah Pemerintah Daerah, verba yang digunakan adalah melarang, dan sasarannya adalah kegiatan perkantoran. Pewarta menyebutkan institusi dari Anies Baswedan yaitu Pemerintah Daerah yang menunjukkan bahwa Anies masih dianggap lemah.

Dari sudut appraisal sikap, pewarta menggunakan afeksi negatif menggunakan kata kerja melarang dan membatasi. Melalui hal ini, pewarta seolah hendak memicu respon emosi pembaca berupa perasaan dibatasi dengan adanya kata larangan. Untuk amplifikasi yang digunakan pewarta adalah amplifikasi fokus yang negatif dengan menggunakan frasa harus sebagai sebuah kewajiban. Pewarta juga 
menggunakan frasa tidak lagi sebagai amplifikasi intensifier meninggi yang negatif, yang menunjukan puncak keadaan sesuatu. Untuk penilaian sikap sumber, pewarta masih mengunakan heteregloss berupa penggunaan sumber dirinya sendiri dan nara sumber yang pendapatnya dikutip sebagai penguat tulisannya.

5. Pemerintah DKI juga bakal menutup kembali tempat wisata yang dikelola pemerintah DKI seperti Ancol, Ragunan dan Monas. Sama seperti PSBB Jilid 1, seluruh usaha makanan seperti rumah makan diperbolehkan buka tetapi tidak boleh menerima pengunjung untuk makan di tempat "Hanya boleh menerima pesanan untuk dibawa pulang atau diantar," ujarnya.

Dari aspek kosa kata, kutipan ini menggunakan kata bakal yang merupakan modalitas epistemik yang menunjukkan kemungkinan (Damayanti, 2012). Penggunaan modalitas ini untuk menunjukkan sikap pembicara terhadap apa yang mungkin akan dilakukan di masa mendatang yaitu menutup tempat wisata. Kutipan ini juga menggunakan modalitas deontik berupa kalimat negasi dari izin (Damayanti, 2012). Agen tidak mengizinkan suatu proses tindakan, dalam hal ini menerima tamu. Dari sudut gramatikal, ketransitifan ditunjukkan dengan verba proses perbuatan dikelola yang menunjukkan pasifasi. Menurut Fairclough (dalam Muhajir, 2018) proses pasifasi dilakukan untuk melindungi agen serta menghindari pemborosan kata. Dalam hal ini pewarta tetap memunculkan agen dalam pasifasi ini. Dengan demikian sosok Anies dimunculkan sebagai aktor yang bertanggung jawab dalam proses tindakan berupa larangan atau penutupan tempat wisata.

Dari tinjauan appraisal sikap afeksi, pewarta menggunakan frasa kata kerja bakal menutup yang bermakna negatif. Frasa ini mengandung ancaman yang dapat memicu emosional pembaca. Untuk amplifikasi penguatan, pewarta menggunakan penguatan menurun dengan kata diperbolehkan. Hal ini menunjukkan penurunan jika dibandingkan dengan proses sebelumnya yaitu pelarangan. Sebaliknya, pewarta juga menggunakan amplifikasi intensifier negatif yang menaik dengan penggunaan frasa hanya boleh dan tidak boleh. Frasa ini merupakan tingkat akhir dari sebuah proses boleh, hanya boleh, dan tidak boleh. Untuk penilaian sikap sumber, pewarta masih mengunakan heteregloss berupa penggunaan sumber dirinya sendiri dan narasumber yang pendapatnya dikutip sebagai penguat tulisannya.

6. Dalam masa PSBB kali ini, tempat ibadah akan melakukan penyesuaian. Tempat ibadah masih boleh dibuka, namun dengan penerapan protokol yang sangat ketat. "Artinya, rumah ibadah raya, yang jamaahnya dari berbagai daerah, seperti Masjid Raya, belum boleh buka," kata Anies. Di sisi lain, rumah ibadah di kampung, untuk warga di kampung tersebut, masih boleh buka. Sedangkan khusus daerah yang memiliki jumlah kasus tinggi, kegiatan beribadah harus dilakukan di rumah. "Lebih baik bila beribadah dilakukan di rumah."

Dari aspek kosa kata, kutipan ini menggunakan modalitas intensional akan yang merupakan penanda keinginan, dalam hal ini akan melakukan penyesuaian. Kutipan ini juga menggunakan modalitas deontik boleh yang merupakan izin dan belum boleh sebagai pelarangan. Modalitas lain yang digunakan adalah diksi harus sebagai modalitas aletis (Prihantoro \& Fitriani, 2015). Dari sudut gramatikal, kutipan ini menggunakan pasifasi dengan proses perbuatan dibuka dan dilakukan. Dalam hal ini agen tidak dimunculkan. Kutipan ini juga menggunakan nominalisasi tidak bernyawa tempat ibadah menjadi penghilangan agen yang menekankan pada peristiwa (Fairclough dalam Muhajir, 2018). Hal ini menyebabkan identitas aktor/agen menjadi tidak jelas. 
Dari tinjauan appraisal sikap afeksi, pewarta menggunakan frasa kata kerja akan melakukan yang bermakna negatif karena mengandung ancaman yang dapat memicu emosional pembaca. Untuk amplifikasi, pewarta menggunakan fokus yang menguat berupa penguatan dari kondisi masih boleh buka dan belum boleh buka. Pewarta juga menggunakan fokus menguat dengan frasa lebih baik hingga harus dilakukan di rumah. Untuk penilaian sikap sumber, pewarta masih mengunakan heteregloss berupa penggunaan sumber dirinya sendiri dan nara sumber yang pendapatnya dikutip sebagai penguat tulisannya. Pewarta hendak mengrontuksikan Anies sebagai agen dalam pelaksanaan kebijakan PSBB dan pembatasan dengan diksi larangan dan amplifiasi sehingga kontsruksinya berkesan negatif.

7. Dalam kondisi Jakarta darurat Covid-19 ini, Ketua DPRD DKI Jakarta Prasetyo Edi Marsudi meminta Anies Baswedan segera memetakan kawasan rukun tetangga sebagai wilayah mikro berstatus zona merah Covid-19. Politikus PDI Perjuangan itu mendorong pemerintah mengawasi ketat kawasan yang masuk zona merah Covid-19 saat penerapan PSBB. "Karena memang wilayah di zona merah ini menjadi bahaya kalau tidak dijaga. Sudah lama Jakarta zona merah. Yang terpenting di sini, PSBB mikro dengan pengawasan di RT, RT itu," katanya.

Dari aspek kosakata, berita ini menggunakan diksi mendorong yang bermakna mendesak/memaksa agar berbuat sesuatu. Kata mendorong bersinonim dengan kata menganjurkan. Namun, kata mendorong kesan lebih mendesak dari sekedar anjuran. Melalui pemilihan kata mendorong, pewarta seolah mau mengesankan jika ini adalah apa yang diminta merupakan sesuatu yang harus dilakukan. Secara gramatikal, kutipan ini menggunakan ketransitifan agen, proses tindakan, dan objek tindakan. Dalam hal ini, Ketua DPRD DKI Jakarta bertindak sebagai agen/aktor yang meminta, sebagai proses tindakan, kepada Anies Baswedan sebagai objek proses tindakan. Agen tersebut juga digambarkan tidak hanya meminta, tetapi juga mendesak agar objek proses tindakan melakukan pengawasan ketat. Hal ini seolah menggambarkan jika sebelumnya belum ada langkah pengawasan ketat.

Sistem appraisal berupa sikap yang digunakan afeksi dengan menggunakan kata sifat bahaya. Penggunaan kata tersebut dapat memunculkan reaksi emosional bagi pembaca berupa rasa bahaya yang mengancam kehidupan, sedangkan dari aspek amplifikasi, pewarta menggunakan amplifikasi kekuatan meninggi dengan menggunakan metafora frasa zona merah. Warna merah melambangkan kondisi darurat. Jika dibandingkan dengan metafora warna lainnya yaitu hijau sebagai perlambang kondisi aman dan kuning sebagai metafora kondisi waspada, maka merah adalah metafora keadaan darurat. Melalui penggunaan kata dan frasa tersebut pewarta seperti menguatkan betapa parahnya kondisi DKI Jakarta akibat pandemi. Amplifikasi lain yang digunakan adalah fokus menguat dengan frasa yang terpenting. Frasa tersebut merupakan tingkat akhir dari proses penting, lebih penting, dan yang terpenting. Hal ini menguatkan bahwa kebijakan yang harusnya diambil adalah PSBB mikro bukan seluruh wilayah yang diajukan oleh Anies Baswedan, Untuk aspek sumber sikap, kutipan di sini menggunakan heterogloss yaitu pewarta dan Ketua DPRD DKI Jakarta. Dalam tulisannya seolah pewarta ingin menunjukkan ke pembaca bahwa tulisannya adalah suatu yang objektif dan akurat dan sebagai penguat bahwa kebijakan PSBB yang diambil oleh Pemda DKI Jakarta bukanlah solusi satu-satunya seperti yang sudah disampaikan oleh Anies Baswedan sebelumnya. 
8. Untuk memperkuat pengawasan pelanggaran protokol Kesehatan di DKI Jakarta, Prasetyo menyarankan Anies untuk bersinergi dengan TNI-Polri. Polda Metro Jaya telah sepakat menggelar Operasi Yustisi untuk menertibkan pelanggaran masker, yang ditengarai sebagai penyebab gagalnya upaya pengendalian Covid-19 di ibu kota. Namun tidak ada sanksi tegas yang akan diberlakukan terhadap para pelanggar protokol Kesehatan PSBB. Peraturan Gubernur (Pergub) Nomor 51 Tahun 2020 hanya memberlakukan dua sanksi yang bisa dipilih oleh pelanggar, yaitu membayar denda Rp 250 ribu atau melakukan kerja sosial selama satu jam. Bisa ditebak, sanksi menyapu jalan menjadi pilihan favorit para pelanggar.

Dari aspek kosakata, berita ini menggunakan diksi meyarankan yang bermakna menganjurkan agar berbuat sesuatu. Kata menyarankan bersinonim dengan kata mendorong. Namun, kata menyarankan lebih berkesan positif. Melalui pemilihan kata menyarankan, pewarta seolah mau mengesankan jika ini adalah apa yang diminta merupakan suatu saran yang bisa dilakukan. Secara gramatikal, kutipan ini menggunakan ketransitifan agen, proses tindakan, dan objek tindakan. Dalam hal ini, Prasetyo, Ketua DPRD DKI Jakarta, bertindak sebagai agen/aktor yang menyarankan, sebagai proses tindakan, kepada Anies Baswedan sebagai objek proses tindakan bersinergi atau bekerja sama dengan TNI Polri. Hal ini mengesankan bahwa sebelumnya langkah ini belum dilakukan oleh Pemda DKI Jakarta. Dengan demikian jelas, sebelum mengambil tindakan kebijakan PSBB seluruh wilayah seharusnya pihak Pemda melakukan kerja sama dengan unsur lain yang terkait. Kutipan ini juga menggunakan pasifasi Namun tidak ada sanksi tegas yang akan diberlakukan terhadap para pelanggar protokol Kesehatan PSBB sehingga terjadi penghilangan agen yang kemudian menekankan pada peristiwa (Fairclough dalam Muhajir, 2018)

Sistem appraisal berupa sikap yang digunakan penghakiman negatif dengan menggunakan kata sifat gagal. Kata ini memberikan penilaian dari nara sumber terhadap kebijakan yang telah diambil oleh Anie Baswedan sebelumnya, sedangkan dari aspek amplifikasi, pewarta menggunakan amplifikasi kekuatan intensifier meninggi dengan menggunakan metafora kata kerja memperkuat. Melalui penggunaan kata tersebut pewarta seperti menguatkan bahwa sebelumnya Pemda DKI Jakarta belum melakukan tindakan penguatan pengawasan sehingga hal inilah yang mengakibatkan penanganan covid -19 mengalami kegagalan. Amplifikasi lain yang digunakan adalah fokus menurun dengan frasa tidak ada sanksi tegas. Frasa tersebut merupakan tingkat akhir dari proses tegas, kurang tegas, dan tidak tegas. Hal ini menguatkan bahwa kegagalan ini disebabkan oleh kebijakan yang diambil Anies belum bersinergi dengan unsur pemerintahan lainlah yang menjadi sumber kegagalan, Untuk aspek sumber sikap, kutipan di sini menggunakan heterogloss yaitu pewarta dan Ketua DPRD DKI Jakarta. Dalam tulisannya seolah pewarta ingin menunjukkan ke pembaca bahwa tulisannya adalah suatu yang objektif dan akurat dan sebagai penguat bahwa kondisi kegagalan penanganan saat ini adalah kesalahan Anies Baswedan dan Pemda DKI Jakarta yang tidak melakukan pengawasan ketat dan bersinergi dalam menghadapi masalah.

9. Selain menghadapi masalah pelanggaran PSBB, Anies Baswedan juga harus menjalin koordinasi dengan daerah penyangga agar penerapan PSBB Jilid 2 dapat berjalan maksimal. Hal ini juga digarisbawahi oleh Prasetyo. "Seluruh upaya dan kebijakan aturan dalam PSBB di DKI Jakarta harus juga dilakukan di daerah penyangga, harus linier ini, kalau enggak percuma bos," ucapnya. 
Dari aspek kosakata, berita ini menggunakan diksi menjalin yang bermakna mengadakan hubungan atau ikatan. Kata menjalin ini mengandung makna bahwa sebelumnya belum ada hubungan dengan pihak lain yang terkait. Secara gramatikal, kutipan ini menggunakan ketransitifan agen, proses tindakan, dan objek tindakan. Dalam hal ini, Anies Baswedan, bertindak sebagai agen/aktor yang harus menjalin, sebagai proses tindakan, koordinasi sebagai objek proses tindakan dengan daerah penyangga. Hal ini mengesankan bahwa sebelumnya langkah ini belum dilakukan oleh Pemda DKI Jakarta. Dengan demikian jelas, sebelum mengambil tindakan kebijakan PSBB seluruh wilayah seharusnya pihak Pemda melakukan kerja sama dengan unsur lain yang terkait, yaitu daerah penyangga. Sebagai Pemerintah daerah, sebenarnya Pemda DKI Jakarta memiliki kewenangan untuk melakukan Kerja sama antardaerah, menurut Peraturan Pemerintah Nomor 50 Tahun 2007, adalah kesepakatan antargubernur, antara gubernur dengan bupati/wali kota, antara bupati/wali kota dengan bupati/wali kota wilayah lain, dan/atau antargubernur, bupati/wali kota serta pihak ketiga, yang disusun secara tertulis serta menimbulkan hak dan kewajiban. Rahayu (dalam Pramesi, 2020) menyebutkan bahwa UU No. 9 tahun 2015 juncto UU No. 23 Tahun 2014 menjelaskan jika daerah harus menjamin keserasian hubungan antardaerah dengan daerah lainnya yang didasari pada pertimbangan efisiensi serta efektivitas pelayanan publik dan saling memberikan keuntungan. Hal ini bermakna bahwa Pemda DKI sudah seharusnya melakukan kerja sama dengan wilayah penyangga dalam penangganan covid 19.

Sistem appraisal berupa sikap yang digunakan afeksi negatif dengan menggunakan kata benda pelanggaran. Kata ini memicu emosional pembaca bahwa Pemda DKI Jakarta seolah melakukan pembiaran terhadap pelanggaran sehingga akhirnya PSBB Jilid 2 harus dilakukan kembali, sedangkan dari aspek amplifikasi, pewarta menggunakan amplifikasi kekuatan fokus menguat dengan menggunakan kata kerja harus dan digarisbawahi. Hal ini menunjukkan bahwa saran agen harus dilakukan oleh Pemda DKI jika mau PSBB Jilid 2 berhasil, utuk aspek sumber sikap, kutipan di sini menggunakan heterogloss yaitu pewarta dan Ketua DPRD DKI Jakarta. Dalam tulisannya seolah pewarta ingin menunjukkan ke pembaca bahwa tulisannya adalah suatu yang objektif dan akurat dan sebagai penguat penanganan saat ini oleh Anies Baswedan dan Pemda DKI Jakarta akan kembali gagal jika tidak melakukan perbaikan-perbaikan.

\section{SIMPULAN}

Berdasarkan analisis kutipan di atas, Anies Baswedan dan Kebijakan PSBB Jilid 2-nya ditampilkan dengan kosakata berupa verba, adverbial, metafora, dan modalitas. Hasil analisis pada gramatika menunjukkan penggunaan konstruksi aktif, pasif, serta negasi. Sistem appraisal yang dihadirkan pada wacana ini dilakukan dari tataran sikap dengan menggunakan afeksi kata sifat, kata benda, dan kata kerja serta penghakiman negatif. Pada tataran amplifikasi, terdapat amplifikasi kekuatan intensifier negatif dengan leksis sikap dan metafora serta fokus yang menguat dan menurun. Dari tinjauan sumber sikap, pewarta menggunakan heteregloss oleh pewarta dan sumber lain yang dikutip pewarta untuk mengevaluasi objek evaluasi, Anies Baswedan dan Kebijakan PSBB.

Berdasarkan hasil temuan ini, peneliti merekomendasikan akan dilakukan penelitian dengan fokus yang sama dengan melibatkan lebih banyak sumber data dari media daring lainnya agar analisis ini bisa dilakukan dari berbagai sudut pandang. 


\section{DAFTAR PUSTAKA}

Andriyanto, S. (2018). Konstruksi berita pasca pelantikan gubernur baru dki jakarta anies baswedan-sandiaga uno periode 2017-2022 (analisis framing robert n. Entman pada media online kompas. Com, detik. Com, dan republika. Co. Id). Universitas Sultan Ageng Tirtayasa. Retrieved from http://eprints.untirta.ac.id/1140/1/KONSTRUKSI BERITA PASCA PELANTIKAN GUBERNUR BARU DKI JAKARTA ANIES BASWEDAN SANDIAGA UNO PERIOD - Copy.pdf

Damayanti, T. (2012). Adverbia penanda modalitas dalam novel karya andrea hirata: suatu kajian stuktur dan makna. Students E-Journal, 1(1), 5. Retrieved from http://jurnal.unpad.ac.id/ejournal/article/viewFile/1277/1265

Fairclough, N. (1995). Critical discourse analysis: the critical study of language.

Fairclough, N. (1996). Language and power discourse.

Hall, S. (1991). Culture, media, language: working papers in cultural studies, 1972-79 (Cultural Studies Birmingham). Retrieved from http://book4you.org/book/ $1002249 / 05 \mathrm{cb} 9 \mathrm{c}$

Halliday, M. A. K., \& Matthiessen, C. M. I. M. (2013). Halliday's introduction to functional grammar: Fourth edition. Halliday's Introduction to Functional Grammar: Fourth Edition. https://doi.org/10.4324/9780203431269

Judge, I. G. H. K. Z., Agus, F. O. S. R. S., Ade, S., \& Apriyansah, H. S. A. (2020). New normal pada industri perbankan di tengah pandemik covid-19. Retrieved from https://digilib.esaunggul.ac.id/public/UEU-Research-16233-5_0342.pdf

Mahsun. (2012). Metode penelitian bahasa tahapan strategi, metode, dan tekniknya. Jakarta: Rajawali Pers.

Martin, J. R., \& White, P. R. . (2005). PRR The language of evaluation: Appraisal in English. London: Palgrave.

Martin, J. R., \& Rose, D. (2003). Working with discourse: Meaning beyond the clause. Bloomsbury Publishing.

Maulana, A. (2020). Efektivitas pembatasan sosial berskala besar (PSBB) sebagai salah satu upaya menekan penyebaran covid-19 di DKI Jakarta. Universitas Negeri Jakarta. Retrieved from http://repository.unj.ac.id/9940/3/BAB 2.pdf

Muhajir, M. (2018). Tata bahasa sebagai cerminan nilai ideologis wacana politik perempuan dalam "kolom perempuan": Kajian analisis wacana kritis atas teks di harian suara merdeka. Tamaddun: Jurnal Kebudayaan dan Sastra Islam, 18(1), 64-82. Retrieved from http://jurnal.radenfatah.ac.id/index.php/tamaddun/article/ download/2316/1681 
Nurdiyani, N. (2020). Amplifikasi di dalam maklumat Ganjar Pranowo (Kajian linguistik sistemik fungsional). Orbith: Majalah Ilmiah Pengembangan Rekayasa dan Sosial, 16(2), 132-138. Retrieved from http://wer23.com/index.php/orbith/ article/download/2100/106912

Pramesi, P. N. (2020). Kerja sama antar daerah: Problem konektivitas Kota Depok sebagai penyangga DKI Jakarta dalam wilayah Megapolitan Jabodetabek. Universitas Airlangga. Retrieved from http://repository.unair.ac.id/99498/4/4. BAB I PENDAHULUAN.pdf

Prihantoro, E., \& Fitriani, D. R. (2015). Modalitas dalam teks berita media online. Prosiding PESAT, 6. Retrieved from http://ejournal.gunadarma.ac.id/index.php/ pesat/article/download/1364/1211

Simanjuntak, S. (2018). Analisis semiotik pidatopelantikan Gubernur DKI Jakarta Anies Baswedan. Jurnal Dakwah Dan Komunikasi, 3(2), 101-120.

Simpson, P. (1993). Language, ideology and point of view (Interface). London: Routledge.

Sulasih, E. S. (2020). Ketidakefektifan penerapan pembatasan sosial berskala besar (PSBB) di Daerah Khusus Ibukota Jakarta. Binamulia Hukum, 9(1), 67-82. Retrieved from http://fh-unkris.com/journal/index.php/binamulia/article/ download/104/82

Syarifuddinn, M. (2020). Analisis sentimen opini publik terhadap efek PSBB pada twitter dengan algoritma decision tree, knn, dan naïve bayes. INTI Nusa Mandiri, 15(1), 87-94. Retrieved from http://ejournal.nusamandiri.ac.id/index.php/inti/article/ download/1433/687

Wiratno, T. (2018). Pengantar ringkas linguistik sistemik fungsional. Yogyakarta: Pustaka Pelajar. 